\author{
Elżbieta Magdalena Wąsik \\ Adam Mickiewicz University in Poznań, Poland
}

\title{
NATURALNESS OF CHANGEABILITY AND VARIABILITY IN CONTACT SITUATIONS - PROPERTIES OF LANGUAGES OR LINGUISTIC FACULTIES OF COMMUNICATING AGENTS
}

\begin{abstract}
Summary. The paper tackles two investigative approaches to the study of mutual influences among languages in which researchers focus either on languages themselves or on communicating individuals. Considering the question of whether and to what extent the contact-conditioned language development results from structural properties of respective languages, or is rather triggered by psychic properties of their speakers, the study exposes, on the basis of selected literature on the subject, a causative role of humans in language contacts. At the same time, it argues that the search for unborrowable language features and structures entails defining naturalness, unmarkedness, and markedness in terms of human abilities. More critically, this paper substantiates the statement that uncovering the rules, which govern the contact-induced language change in terms of communicative properties of humans, implies, for example, the necessity of dealing with identity and group affiliations of multilingual subjects demonstrable, apart from language transfer and lexical and grammatical interference, mostly in codeswitching. Thus, the author argues that the sources of linguistic changeability and variability in contact situations must be read, in the first instance, into the psychic conditionings of socially and culturally determined language speakers. All in all, she tries to prove that linguistic borrowings cannot be examined in accordance with universal applicability or absoluteness but with reference to principles of human perception, memorizing, the ability of association, etc., as well as the economy of effort in communication in conjunction with individual and socio-cultural needs of humans, their knowledge and attitudes.
\end{abstract}

Keywords: communicating individual, differentiation of languages, idiolect, language change, markedness, naturalness.

\section{Approaches to changeability and variability of languages}

Historians of language who study linguistic texts in isolation from their creators usually approach changeability of human-shared means of communication from a diachronic perspective. Investigating and comparing stages of their growth or decay, they try to depict tendencies of linguistic developmental processes and precisely describe alternations occurring at particular levels of linguistic systems. However, as pointed out by Ferdinand de Saussure, a Swiss linguist advocating the view on language as a product of social interactions which has a collective character, changeability of languages is perceived and anticipated by their 
NATURALNESS OF CHANGEABILITY AND VARIABILITY IN CONTACT SITUATIONS PROPERTIES OF LANGUAGES OR LINGUISTIC FACULTIES OF COMMUNICATING AGENTS

speakers only to a little degree. This inability of perceiving the changeable nature of communicative means occurs because, according to Saussure (1916, 1959, pp. 79-100), language evolution is a slow process which may be fully realized when keeping a proper time distance. When looking at it from a synchronic perspective, language is a form realized substantially in the products of individual acts of communication. Therefore, it should be investigated, as Saussure suggested, as a system of pure values which are determined by the arrangement of text elements at a given point of time (cf. also, e.g., Zdzisław Wąsik, 2003, pp. 34-35, 70, 85, 87).

Nevertheless, if language is associated with its standardized variety, some aspects of linguistic changeability could be considered in connection with the territorial and social variability of languages at a specific point of time and the differentiation of language speakers. One might therefore agree with the statement that the specifications of languages and language varieties, made in sociologically-oriented language studies, imply, inter alia, that the speakers of natural languages and their varieties are to be seen as dynamic and heterogeneous subjects who actively communicate with one another in the everchanging reality of everyday life. As participants of communication in concrete situations of social life, they realize their needs and aims and not infrequently resort to different languages and language varieties, such as natiolects and ethnolects, dialects and vernaculars, sociolects and talks, jargons and slangs, styles and registers, etc., utilized as shared means of mutual understanding. One has to remember that, apart from linguistic criteria for the classifications of languages and their varieties, non-linguistic criteria, based, for example, on demographic, geographic, or political factors, being decisive for a systemic differentiation of languages, must also be taken into account (for references see Zdzisław Wasik, 2003, p. 52). As a matter of fact, variations within particular languages, recognized as distinct, depends on the differentiation of their users, situations and domains of use, or communicational requirements of speech communities, and the like. With a view to these aforementioned environmental factors, it is problematical to ascertain in an unambiguous way at which levels of social interaction the language change takes place. If the borderlines between the neighboring languages and dialects are fuzzy, it is an obvious thing to say that languages as social means of communication have a changeable nature because 
their speakers make creative innovations within their systems according to certain rules and principles which may be eventually uncovered by linguists.

\section{The idiolect as an individual communicative means}

There are theories which aim at acknowledging the priority of relationships between a language and a single language speaker. They resort to the notion of idiolect which refers to the linguistic system of a human individual. Regarding the term itself, understood in different ways by different authors, as noticed by Els Oksaar (1987, pp. 293-297), a researcher of language contacts and multilingualism, it was coined in the domain of structural linguistics in America. Its originator, Bernard Bloch (1948, p. 7), one of the most influential postBloomfieldian linguists, applied the term idiolect to a set of possible expressions that a single language speaker uses at a given time, being thereby integrated with other speakers. The idiolect, as a variety of language being unique to an individual, characterizes thus a single communicator who, according to Bloch, may speak, for example, different dialects within the span of different life periods as well as one or more idiolects concurrently.

The reflections on the distinctiveness and uniqueness of language varieties spoken by particular individuals who may differentiate with regard to articulation, vocabulary and grammar, have presumably contributed to a better understanding of the social and mental nature of language as a property of humans. A special exposure deserves here the idea of an individual language developed by Hans-Heinrich Lieb within the framework of his Integrational linguistics (1983) in confrontation with the conception of language as a cognitive system expounded by Sydney MacDonald Lamb in his book Language and illusion (1991). Lieb's and Lamb's lines of argumentation about the notion of the idiolect as an individual means of interpersonal communication entail, however, incommensurable interests of study, focusing either on environmental conditionings of language speakers or on their mental properties. And so, Lieb's (1983, p. 22) theory devoted to language variability in terms of synchrony and diachrony proposes to take into account external conditionings of actual language speakers who exist within a given society in a determined space and time. A set of individual linguistic means usually belongs, in Lieb's (1983, p. 23) assessment, 
NATURALNESS OF CHANGEABILITY AND VARIABILITY IN CONTACT SITUATIONS PROPERTIES OF LANGUAGES OR LINGUISTIC FACULTIES OF COMMUNICATING AGENTS

to a particular language or a language variety, but sometimes it may simultaneously adhere to a number of varieties, such as, e.g., a regional dialect, sociolect, or style of speech. On the basis of his arguments, one can assume that individual language speakers sometimes develop their own sub-varieties of communicative means. Such personal languages are usually constituents of one or more varieties of the same language, but they can also constitute varieties of related or distant languages. Assuming that the communicating individual is the spot where different languages or their varieties meet, one cannot forget about the mixed and non-standardized varieties as constituents of an idiolect or about the instability of individual speakers in the choice of vocabulary and grammar.

Contrary to Lieb, Lamb speaks in favor of defining language as a cognitive system which has a continuous character in the sense that it can be abstracted from all individual and composite linguistic systems of the world. However, despite the fact that humans in general, as language knowers, language doers, or language users, are able to communicate with one another on the basis of verbal signs shared on different levels of social, ethnic, national or international organization, language in the collective sense appears to be, according to Lamb (1991, p. 65), illusive since the neurological structures and thinking processes of linguistic character occur only in the minds of individual selves. As one can infer from Lieb's and Lamb's arguments, only communicative means of an individual are directly accessible to researchers of languages. As to methodological consequences for the study of linguistic changeability and variability, Lieb does not see any difference between the individual means of communication and the idiolects in the traditional sense, treated as sets of abstract texts consisting of form and meaning. In the light of Lamb's (1991, p. 60) mentalist theory, texts are clues to the cognitive nature of linguistic systems that are empirically inaccessible in a direct observation.

An original explanation of individual and collective dimensions of language blending and language differentiation is presented by Norbert Reiter (1986), a German specialist of Balkan-Slavic languages, aware of the haphazard spread of mixed and non-standardized versions of vernaculars and the irregular incidence of their inconsistent speakers on given territories. The first dimension constitutes, in Reiter's (1986, p. 142) conception, the so-called individual record of signs (Germ. der individuelle Zeichenbestand), and the second one, the inter-individual 
repository of signs (Germ. das interindividuelle Zeicheninventar). The individual record of signs including the totality of all linguistic signs which an individual knows at a given point in time may be considered as a synonym of the traditional term idiolect. As far as the inter-individual repository of signs that forms an interindividual set of communicative means is concerned, it may be understood as an alternative term which refers to a sociolect. Ultimately, Reiter (1986, p. 149) arrives at the conclusion that the mutual understanding takes place only when the individual sign reservoirs of at least two individuals correspond to each other, or when there is a similarity between the sign reservoirs of many individuals who aggregate, at a social level, from a dyad into a pleiad.

\section{Naturalness in the approach to language and language change}

The attribute natural, exploited in linguistic works as a synonym of unmarked, usually means the same as 'frequent', 'expected', 'simple', or 'intuitively plausible'. Reflecting upon the claim that the linguistic change supposedly aids, in survival, the unmarked forms which are more natural, rather than the marked ones, one has to consider the meaning of naturalness, defined with reference to mental abilities or predispositions of human individuals by Wolfgang U. Dressler, Willi Mayerthaler, Oswald Panagl, and Wolfgang U. Wurzel (1987). As has been stated by the co-authors of the collective monograph devoted to concepts and strategies of natural morphology in their "Introduction", a more exact understanding of the notion of naturalness is owed to theories of naturalness in phonology and morphonology (cf. Dressler et al. 1983, p. 3). In phonology, it is, namely, used, following the creators of the new investigative field of natural phonology Patricia J. Donegan and David Stampe (1979, p. 126), to the mechanisms of articulatory and perceptual phonetics that consist in a subconscious and systematic adaptation of phonological intentions of language speakers to their phonetic capacities.

Slightly earlier, Roman Jakobson (1962), among other theoreticians of the Linguistic School of Prague, preferred the term markedness over the term naturalness with special reference to a relative unnaturalness in morphology. As a result, exponents of morphological categories, such as, e.g., cases, persons or tenses, in different languages were analyzed according to their relative 
NATURALNESS OF CHANGEABILITY AND VARIABILITY IN CONTACT SITUATIONS PROPERTIES OF LANGUAGES OR LINGUISTIC FACULTIES OF COMMUNICATING AGENTS

markedness and unmarkedness. Jakobson's contribution to the theory of markedness, utilized in the analysis of formal structures of linguistic entities in terms of oppositional binary relations with the aim of defining their meaning, has been evaluated especially by Enda Andrews (1990). As the author of Markedness theory demonstrates (cf. Andrews, 1990, especially pp. 9-13), its usability consists, inter alia, in facilitating to carry out the systematization of oppositions in particular languages and to explain the hierarchy of linguistic categories. Critically, the markedness theory has been adapted in different ways and varieties by many linguists and schools of linguistics. These adaptations might be respectively divided into two main groups, comprising, as Andrews (1990, pp. 15-16) points out, its advocators who "work with meaning" on the one hand, and, on the other, the researchers who only "attempt to describe language as a purely 'formal' system without utilizing meaning".

Practical applications of the theories and conceptions in question have led to the assessment of productiveness and expansiveness of linguistic forms which come to light mostly in the face of language contacts (cf., e.g., the subchapter on "Productivity and diachronic change in morphology" written by Panagl, 1987). If linguistic borrowings of different kind are examined from the viewpoint of markedness, one can often expect, as Viktor Elšik and Yaron Matras (2006, pp. 406-409) conclude, to gain insights into intralinguistic motivations for linguistic changes prompted by language contacts in specific individual cases. Although the idea of naturalness has been associated with universal tendencies governing the development of languages, it is also applied to the search for exceptions from the rules considered as prevalent.

The supporters of natural morphology theory (Dressler et al., 1987, pp. 10-11) admit that natural languages, literally taken, use both natural and unnatural procedures of different kind. They allude in particular to Vladimir Skalička's concept of linguistic types as ideal constructs approximated by natural languages to various degrees. Skalička, a representative of the Prague School of linguistics in modern times, argues in his Typologische Studien (1979) that different constituents of the morphological system, for example, may come closer to different ideal types and, additionally, that particular languages represent more or less perfect if not rather frequently less perfect realizations of ideal language types. In this sense, languages realize the principles of naturalness in an unequal 
measure. Metaphorically speaking, they are somehow determined to choose, as Dressler et al. explain, from the various scales of naturalness, and, consequently, they place, in a disadvantageous position, some linguistic forms for the sake of greater naturalness of some others.

In keeping with the conviction that there is a tendency in the development of languages where the marked forms and patterns are eliminated and the unmarked forms and patterns, as natural, have a better chance of surviving, Dressler et al. (1987, pp. 12-14) state that the feature of naturalness, which has both linguistic and non-linguistic foundations, is a matter of degree. The evidence for naturalness of particular linguistic forms or structures comes, in their opinion, from internal sources, such as, e.g., language typology, frequency, analogy, neutralization, morphology, phonology, syntax, language change, chronology of change, or pidginization and creolization. Accordingly, they put forward a list of initial assumptions and ascertainments that: (1) less marked (natural) elements are dominant in languages of the world, (2) natural categories are more frequent both in types and tokens, (3) less marked (natural) forms more often survive in analogical changes than the marked ones, (4) a zero encoded form usually, but not always, represents a less marked category of the markedness relation, (5) if the phonological exponent of a category is a phonologically marked segment, the morphonologically encoded category is often marked too, (6) the first element of a conventionally ordered pair tends to be less marked or prototypical (in syntactic freezes), (7) there is a tendency that languages change from what is more marked to what is less marked, (8) elements of more marked categories change before the less marked ones, and (9) marked categories disappear in pidgins, whereas unmarked categories reappear as newly introduced categories in creoles.

One has here to pay attention also to the fact that, according to Dressler et al. (1987), higher or lower degrees of naturalness imply the greater or lesser storage capacity of the human mind to acquire certain forms or structures. Moreover, properties of linguistic structures are, in the view of the followers of linguistic naturalness, either determined and prohibited or favored and disfavored by extralinguistic facts. Accordingly, one can assume the existence of: (1) neurological sources of naturalness (which include psychological bases, such as psychological limitations on perception and receptive processing, limitations of 
NATURALNESS OF CHANGEABILITY AND VARIABILITY IN CONTACT SITUATIONS PROPERTIES OF LANGUAGES OR LINGUISTIC FACULTIES OF COMMUNICATING AGENTS

memory, and restrictions on storage or on retrieval of information and on selective attention during productive and receptive activities), and (2) sociocommunicational sources of naturalness (which include sociopsychological bases, such as the speech situation, the social roles of speaker and hearer as well as the speaker's empathy with the hearer's receptive role, processing ease, etc.). All extralinguistic facts, which determine the linguistic facts, interact and limit the choice of linguistic (e.g., morphological) technics open to languages, as they favor some of them and disfavor some others. In reality, as Dressler et al. (1987) put it, extralinguistic facts are the bases of universal linguistic preferences, but, to some extent, they constrain the possibilities of universal language faculty. One has to reckon with the following extralinguistic sources of evidence where the knowledge about naturalness comes from: (1) evolution and maturation (because more marked and, at the same time, less natural are those phenomena which appear late in phylogenesis, while phenomena which come early in ontogenesis are less marked, i.e., more natural); it is expected that linguistic entities or operations, such as, e.g., specialization for analytic processing, being performed in the left hemisphere, are more marked since the functional specification of the two cortical hemispheres seems to be a relatively late evolutional achievement, (2) perception (because forms and structures which are easier perceptible are more natural, i.e., less marked), (3) errors (because forms and structures which evoke relatively less errors and mistakes are assumed to be more natural), (4) speech disturbances (because some of them are less likely to be affected by aphasia), (5) baby talk/motherese, i.e., a child-directed speech form, (because natural language properties occur more frequently in a talk directed to a child), as well as (6) language acquisition (because forms characterized by naturalness are acquired easier and earlier).

As far as language, with regard to its communicative and cognitive functions, is a system of verbal signs, which enables humans to communicate more effectively than with the use of non-verbal signs and which supports the process of cognition guided rather by the application of verbal than the nonverbal signs, the semiotic foundations of natural morphology should constitute a separate issue according to Dressler et al. (1987, pp. 15-17). The point they arrive at in concluding remarks is that language must be flexible and changeable if it has to satisfy the needs of human individuals and to fulfill the communicative 
and cognitive functions at all. As the research has shown, in the opinion of Max W. Wheeler (1993), language change is functionally motivated, but it is motivated as such by both the psychological nature of human individuals and principles of human communication.

\section{On linguistic and nonlinguistic factors favoring and constraining changeability of languages}

The mere questions about linguistic features, namely which are borrowable and which are not and under which conditions, have troubled researchers of languages in contact who focus mainly on natiolects as objects of their study. In addition to them, a separate investigative problem constitutes the degree to which linguistic shifts are dependent upon the state of a recipient language and/or upon the properties of a donor language. Nevertheless, contradictory observations, such as, for example, "a language accepts foreign structural elements only when they correspond to its own tendencies of development" or "interference always complicates the system, making it 'less natural'", quoted by Sarah G. Thomason (2001, pp. 63-65), have proven that there is no consensus among scholars in this area.

Nevertheless, practitioners of linguistic studies are aware of the fact that interlingual contacts may not only be resulting in an ultimate language mixture when contact languages, such as pidgins, creoles, and bilingual mixed languages, come into being, but also in the death of a particular language that languages reach through attrition triggered by the loss of linguistic material or grammatical replacement. What they are principally interested in belongs, in fact, to a more complex issue of language blending connected with the answers to the specific questions about linguistic processes and their consequences which may be formulated on the basis of language-contact typologies by Thomason (2001, p. 60) in the following way. Firstly, how is the hierarchy of investigative predictors of kinds and degrees of contact-induced language changes, especially of such linguistic factors, as universal markedness, degree to which borrowed features are integrated into the linguistic system, typological distance between source and recipient languages, as well as such social factors, as, for example, 
NATURALNESS OF CHANGEABILITY AND VARIABILITY IN CONTACT SITUATIONS PROPERTIES OF LANGUAGES OR LINGUISTIC FACULTIES OF COMMUNICATING AGENTS

intensity of contact, presence vs. absence of imperfect learning, and speakers' attitudes? Secondly, what are the effects of language contacts on the recipientlanguage structures in regard to the loss of features, addition of features and replacement of features? And thirdly, to which extend such psychic mechanisms, as codeswitching, code alternation, passive familiarity, negotiation of meaning, second-language acquisition strategies, first-language acquisition effects, and deliberate decision (can) lead to contact-induced changes?

Having discussed and evaluated attempts of empirical linguists aiming at discovering the universality of rules in the domain of language change, Thomason (2001) expresses her opinion that it is improbable whether any substantive linguistic constraints would ever turn out to be absolutely proven or valid. As a result of many detailed studies, she notices the need for elaborating the socalled borrowing scales, which must be considered rather as a matter of probabilities than certainties that an anticipated linguistic change will occur. In such a borrowing scale provided by Thomason (2001, pp. 70-71) who regards different degrees of bilingualism as a property of individuals, the effects of language blending are characterized with respect to the intensity of contacts between language bearers, specifically as: (1) casual, (2) slightly more intense, (3) more intense, and (4) intense.

And so, in the case of casual contacts, borrowers do not necessarily need to be fluent in the source language and among borrowing-language speakers there are rather few bilinguals indeed. On such occasions, only selected items of non-basic vocabulary, as especially content words, most often nouns, but also verbs, adjectives, and adverbs, are borrowed; hence, no changes in the linguistic structure occur at all. According to Thomason (2001, p. 72), the observation that lexical borrowings can occur even in the total absence of bilingualism of any kind is validated by mutual influences between modern English and French in the United Kingdom and the United States as well as in France where the flood of English loanwords invades the French language in spite of the persistent efforts of the government.

Slightly more intense contacts take place when borrowers are quite fluent bilinguals, but they constitute a minority among borrowing-language speakers. In such situations, still non-basic vocabulary, not only content words but also function words, such as conjunctions and adverbial particles, is the object of 
borrowing. There are only few grammatical borrowings which alter the types of structures in a borrowing-language. New phonological features (i.e., phonemes) are realized by new phones, but only in loanwords. What might also occur are new functions or functional restrictions for some previously existing syntactic structures, or the usage of previously rare word orders. In Thomason's (2001, p. 73) estimation, suitable instances of not-entirely-casual contact situations consist of increased bilingualism among Siberian Yupik Eskimo speakers acquiring Russian during the Soviet period, the impact of Arabic on the languages of various peoples for whom Classical Arabic is the sacred language of their Moslem religion, or the various kinds of influences of Sanskrit, the sacred language of the Hindu religion, on some literary Dravidian languages.

More intense contacts are characterized by a greater number of bilinguals whose attitudes as well as other social factors favor borrowing processes, so that the basic and non-basic vocabulary is borrowed and the grammatical structures are subjected to changes. In particular, more function words, the kinds of words present in all languages, including pronouns and low numerals as well as nouns, verbs and adjectives, derivational affixes, etc., are borrowed. Moderate structural borrowings do not result in major typological changes in the target language. In phonology, one observes the loss of some native phonemes not present in the source language, addition of new phonemes even to the native vocabulary, or the modification of prosodic features, such as stress placement, loss or addition of syllable structure constraints, and changes in morphophonemic rules. In syntax, one detects changes in word order and in the coordination and subordination of sentences. Morphology in turn is characterized by borrowings of inflectional affixes and categories added to native words. Such linguistic changes have been observed in Thomason's account (2001, pp. 73-74), inter alia, in the case of borrowings from Caucasian languages, particularly Georgian, into the Iranian language Ossetic.

In intense contacts, very wide-ranging bilingualism among language speakers as borrowers and the adaptation-favorable social conditionings contribute to changes consisting in heavy lexical and grammatical borrowings. Potential changes may come into being: in phonology, especially through the loss or addition of entire phonetic categories in native words, and through all kinds of morphophonemic rules, in syntax - far-reaching changes in the word order, 
NATURALNESS OF CHANGEABILITY AND VARIABILITY IN CONTACT SITUATIONS PROPERTIES OF LANGUAGES OR LINGUISTIC FACULTIES OF COMMUNICATING AGENTS

relative clauses, negation, coordination, subordination, comparison, and quantification, and in morphology - the replacement of inflective by agglutinative word forms, or vice versa, the addition or loss of derivational categories unequal in source and borrowing languages, and the extensive loss or addition of agreement patterns. Consequently, Thomason (2001, e.g., pp. 11, 74) argues that, when all aspects of language structure are transferred from one language to another, as in the case of Turkish influences on Asia Minor Greek, the new kinds of mixed languages come into being which bilinguals acknowledge as a symbol of their emerging ethnic identity.

Since most exceptions from these rules are found in contact situations involving two typologically similar languages, the reason for such a state of affairs is unquestionable that some structural features are easier to adapt for speakers of certain languages than the others. Borrowings of all kinds can be in fact incorporated without much effort into typologically similar structures, but a greater intensity of contacts is necessary for the borrowing of structures into typologically different languages. As for other reasons of unpredictability of contact-induced changes, attitudes that language speakers may take toward themselves, toward speakers of other languages as well as towards the means of communication, both the native and the foreign ones, are acknowledged as being of particular importance. In view of that, Thomason (2001, pp. 77-85) argues that language attitudes can and usually do produce exceptions to most of the generalizations concerning the processes of linguistic borrowings she presents. Language speakers' attitudes as a psycho-sociological factor are ultimately assumed to be responsible for the failure of substantive predictions about language changes induced by language contacts.

\section{The communicating individual as an active subject in interlingual contacts}

Languages are in (dis)continuous contacts because language speakers (and learners) as individual communicators participate in communicational events simultaneously and successively. It is indeed they who select appropriate means and ways of verbal expression according to their needs and their own assessment of the requirements of mutual understanding. They decide, consciously or not, 
about the use of particular linguistic forms and structures in concrete speech acts. Social relationships in which they take part forming temporary, long-lasting, and permanent communication links and chains are usually characterized in accordance with demographic, political, psychological, interactive, cultural, or situational criteria. In this particular context, worth quoting is the meaningful statement which describes a bilingual individual, who combines competences in two languages and who speaks them in situations of everyday life, while playing the social role of a performer in language-contact and language-change situations:

\begin{abstract}
„The high hurdler blends two types of competencies, that of high jumping and that of springing. When compared individually with a springer or a high jumper, the hurdler meets neither level of competence, and yet when taken as a whole a hurdler is an athlete in his or her own right. (...) A high hurdler is an integrated whole, a unique and specific athlete (...). In many ways, the bilingual is like the high hurdler: an integrated whole, a unique and specific speaker-hearer, and not the sum of two complete or incomplete monolinguals." (cf. Francois Grosjean 2008, p. 14)
\end{abstract}

Observations regarding the regulation of social behavior of humans that have been made by psychologists, critically evaluated, inter alia, by Mahzarin R. Banaji and Deborah A. Prentice (1994, pp. 297-232, cf. especially 298-299) are relevant also in multilingual contexts and interlingual contacts. Due to their findings, the dynamism of human nature finds its expression within concrete social contexts in which individuals pursue their goals of self-enhancement, selfknowledge and self-improvement through the processes of social reasoning, social comparison, social interaction, self-presentation, and collective identification. Importantly, the primary aim of investigations conducted by psychologists is seen in the description of strategies which human selves choose to pursue their goals in social contexts. The choice of communication strategies with the use of communicative means of languages and their varieties available to a human individual is made according to how the individual self directs its cognition and behavior in social reality of everyday life (cf. also respective bibliography in Banaji, Prentice 1994). As Banaji and Prentice (1994, p. 322) argue, the relation between the self and social behavior is bidirectional because 
NATURALNESS OF CHANGEABILITY AND VARIABILITY IN CONTACT SITUATIONS PROPERTIES OF LANGUAGES OR LINGUISTIC FACULTIES OF COMMUNICATING AGENTS

the strategies which the communicating individuals adapt usually affect their selfconcepts.

As a matter of fact, individual and social strategies of language choice resulting in language-mixing processes are different kinds of the so-called codeswitching. According to, for example, Yaron Matras (2009, p. 101), the situation of codeswitching, which has been regarded from the viewpoint of normative grammarians as corruption of language, has recently formed the field of investigation guided by its own rules. Researchers, focusing, on the one hand, on situational and contextual motivations for the switching between languages and, on the other hand, on structural characteristics of codeswitching, aim at identifying general patterns of language mixing. They are convinced that the mere fact of codeswitching is not entirely arbitrary but follows regularities which must be detected. It must be thus functional with respect to language speakers, who are continuously driven by factors, changing in effect of ongoing communication, to switch between languages or language varieties for purposes that sometimes vary even in the same conversation. At the current state of knowledge, one can assume, after Matras (2009, pp. 101, 105), that language mixing in communication, called more broadly codemixing, consists either in the insertion of a word or phrase into an utterance or sentence, formed in a particular base language or frame language (insertional codeswitching), or in the alternations of languages between utterances or sentences (alternational codeswitching). These changes based on language mixing are seen as forced by various levels of control over language processing and as caused by difficulties in finding adequate means of expression in a particular language, by stylistic effects and creative structuring of speech, by language-specific associations evoked during the conversation, etc.

On the margin of this discussion, it is worthwhile to mention a distinction, explicitly outlined by Grosjean (cf. especially 2001, p. 3, and 2008, p. 36), between two kinds of phenomena occurring in the so-called language modes, namely, codeswitching that appears in a bilingual mode and language interference that occurs in a monolingual mode. Hence, such mixing of languages which takes place in the bilingual mode is viewed as depending on goals and aims realized by bilingual individuals in encounters with others in different domains of life and different communicative situations. In the realization of such goals and 
aims, they usually process their two languages being determined by their subjective understanding of the specificity of a social situation at a particular moment in time. For practical and theoretical purposes, it is, however, hard to distinguish codeswitching from borrowing for the lack of precise criteria in this respect. While codeswitching is typically understood as a single-word insertion in the conversation of bilinguals, borrowing is in general understood as a diachronic process through which languages enrich their vocabulary and/or grammar. Admittedly, established borrowings are customarily identified as distinguishable from spontaneous inclusions of words from one language into another (1) by the frequency of their occurrence (although there are no uniform standards which might be helpful in measuring this occurrence), and/or (2) by the degree of structural integration of the item (although structural integration occurs in the speech of bilinguals independently of the frequency of use). It is thus obvious (as argued, e.g., by Matras 2009, p.p. 106, 110) that mixing of languages in conversation takes place at different levels, with the employment of different strategies, whereas the pursuit of different communicative goals results in a variety of structural outcomes. This fact authorizes researchers to speak about the codeswitching-borrowing continuum. Since the distinction between borrowing and codeswitching involves a number of criteria, each of which, nevertheless, can be arranged on a continuum, Matras (2009, pp. 113-114) defines some exclusively extreme cases of language-mixing situations where selected examples of borrowing and codeswitching occupy their places between least and most controversial limits. And so, the regularity of occurrences of a single structurally integrated lexical item, used in a monolingual context as a default expression for designating a unique referent or a grammatical marker, is pondered as the least controversial example of borrowing. In turn, the least controversial codeswitching, which is characterized by a single occurrence, consists in the alternation of a word or phrase at an utterance level made by a bilingual individual through a conscious choice for special stylistic effects. As Matras (2009, p. 138) ultimately insists, "the full continuum between 'switching' and 'borrowing' appears visible not just by comparing different case studies, but even when focusing on individual bilingual communities".

Applying the notion of markedness in a modified sense, Matras (2009, pp. 114-116) discerns the complexity of rules according to which the selection of 
NATURALNESS OF CHANGEABILITY AND VARIABILITY IN CONTACT SITUATIONS PROPERTIES OF LANGUAGES OR LINGUISTIC FACULTIES OF COMMUNICATING AGENTS

codes proceeds in dependence on situational and conversational conditionings. The marked choices of codes which serve speakers to signal either disidentification with their interlocutors or another feature of a given conversation are rather unexpected. But the speakers also make unmarked choices in order to express their social identity and social relationships in certain settings. It is important therefore to realize when the choice of language is indexical, i.e., when it does not result from social values or rules but constitutes evidence of the acceptance or non-acceptance of those values and rules which are determined by a speaker at any particular moment in a conversation. For researchers, it is unclear why speakers sometimes disobey the same conventions and make marked choices. In fact, only the choice of unmarked codes is predictable in communication because it is made according to social conventions. One can assume that individual speakers who contrast languages strategically may act rationally and calculate possible risks and gains and in this way take advantage of the social meanings associated with their languages.

Bearing in mind the role of a bilingual individual, codeswitching happens to be discourse-functional, as has been illustrated on the basis of selected publications by Matras (2009, pp. 116-117, cf. also p. 129). This implies that codeswitching mostly signals transitions between various layers of discourse. Moreover, in metaphorical codeswitching language alternation signals contrasts between different stretches of speech. Participant-related codeswitching indicates a change in the participant constellation, addressee selection, inclusion or exclusion of observers, etc., while conversation-oriented codeswitching highlights in particular reported speech, parentheses or side-comments, reiterations or quasi translations for emphasis, change of mode (e.g., from formal interview to informal conversation), language play, and topicalization. Being bilingual and having at their disposal a wider repertoire of linguistic means than in the case of monolinguals puts a communicating individual before the opportunity to express a full range of meanings and to apply a broader set of conversational strategies for achieving a more useful variety of innovative effects in communication.

As has been argued by Matras (2009, pp. 129-136), investigations of structural aspects of codeswitching, with the aim of finding its formal regularities and formulating fundamental generalizations, can lead to a constructive ascertainment that even though it cannot be treated as a corrupt form of speech, 
it "remains to a considerable extent the creative, improvised composition of individual speakers wishing to take advantage of the enormous assortment of nuances that their complex, multilingual repertoire affords" (Matras, 2009, p. 136). Systematic studies of codeswitching conducted recently, as highlighted by Matras (2009, p. 145), have authorized researchers to formulate a generalization that individual aspects of the speech performance of bilinguals are related to some social aspects of bilingualism because they determine to what extent the innovations introduced by particular speakers are widely accepted by other members of a given speech community.

\section{Concluding remarks}

Theoretical findings of researchers who have dealt with the study of natural conditions fostering or constraining lexical and grammatical changes in languages and thus contributing to the formation of language varieties may be subsumed under the following premises and ascertainments. Firstly, there are no natural features of language; secondly, it is not the natural laws which govern the development of language; and finally, the development of language depends on conscious and unconscious or motivated and non-motivated choices of verbal means, utilized for the attainment of tasks and goals aimed at by human subjects. If the notion of naturalness were applicable to the characteristics of communicational strategies, it should rather be referred to the description of internal and external conditionings of both the subjective knowledge of individuals based on their experience and the intersubjective knowledge imposed upon them by other individuals through interindividual communication. Important would be here to pay also attention to some nonlinguistic facts, especially, to social and cultural conditionings of human individuals as members of societies. The same statement might be referred to the validity of naturalness and markedness theories the aim of which is to approximate, explain and predict the sources of language changes.

Consequently, the results of thoroughgoing inquiries into the causes of systemic changeability and variability of languages have led researchers in question to the consideration of particular interests of human individuals and their individual sets of communicative means which they activate in socializing 
NATURALNESS OF CHANGEABILITY AND VARIABILITY IN CONTACT SITUATIONS PROPERTIES OF LANGUAGES OR LINGUISTIC FACULTIES OF COMMUNICATING AGENTS

encounters. In view of this, practitioners of contact-linguistics studies have aimed at uncovering and systematizing the principles of language change while going also beyond linguistic facts. So far, having considered psychologically determined uses of linguistic means, they have discerned that mixing of languages depends, in the last instance, on unmarked (language-system-driven) or marked (subjective-preference-driven) choices of strategies performed by individual communicators as members of speech collectivities in particular communicative situations of everyday life. It is obvious, therefore, that the contact-induced language change starts already when items from a certain language happen to be introduced into another one by communication participants who are bilingual, or simply, when they earlier have been partly exposed to another (foreign) language. To sum up, one must emphasize that the effects of different kinds of multilingualism in society should be described not only in terms of borrowing but also codeswitching. In both cases, the driving force of language change is to be seen therefore in the competition and cooperation between individual and collective dimensions of the human self as a person taking part in interpersonal communication. Hence, it is the communicating individuals, having at their disposal linguistic means differentiated in time and space, who really sustain multilingualism thanks to their mental conditionings if they are intertwined with one another through the realization of their communicative purposes.

\section{References}

Andrews, E. (1990). Markedness theory. The union of asymmetry and semiosis in language. Druham, London: Duke University Press.

Banaji, M. R., \& Prentice, D. A. (1994). The self in social contexts. Annual Reviews of Psychology, 45, 297-232.

Bloch, B. (1948). A Set of Postulates for Phonemic Analysis. Language, 24, 3-46. Donegan, P. J., \& Stampe, D. (1979). The study of natural phonology. In D. A. Dinnsen (ed.) Current approaches to phonological theory (pp. 126-173). Bloomington: Indiana University Press.

Dressler, W. U., Mayerthaler, W., Panagl, O., \& Wurzel, W. U. (1987). Introduction, In Dressler, W. U., Mayerthaler, W., Panagl, O., and 
Wurzel, W. U. Leitmotifs in natural morphology (pp. 3-24). Amsterdam, Philadelphia: John Benjamins.

Elšik, V., \& Matras, Y. (2006). Markedness and language change: The Romani sample. Berlin, New York: Mouton de Gruyter.

Grosjean, F. (2001). The bilingual's language modes, In Nicol, J. (ed.) 2001. One mind, two languages: Bilingual language processing, pp. 1-22. Oxford: Blackwell.

Grosjean, F. (2008). Studying bilinguals. Oxford: Oxford University Press. Jakobson, R. (1962). Selected writings. The Hague: Mouton.

Lamb, S. M. (1991). Language and illusion. Toward a cognitive theory of language. Houston TX: Rice University.

Lieb, H.-H. (1983). Integrational linguistics. Vol. I: General outline. Amsterdam: John Benjamins.

Matras, Y. (2009). Language contact. Cambridge, UK: Cambridge University Press.

Oksaar, E. (1987). Idiolekt. In U. Ammon, N. Dittmar and K. Mattheier (Eds.) Sociolinguistics: An international handbook of the science of language and society, pp. 293-297. Berlin, New York, NY: Walter de Gruyter.

Panagl, O. (1987). Productivity and diachronic change in morphology. In Dressler, W. U., Mayerthaler, W., Panagl, O., and Wurzel, W. U. (1987). Leitmotifs in natural morphology, pp. 127-152. Amsterdam, Philadelphia: John Benjamins.

Reiter, N. (1986). Die Irrtümer um den Idiolekt. Incontri Linguistici, 11, 137-151. Saussure, F. de (1916/1959). Cours de linguistique générale. Publié par Charles Bally et Albert Sechehaye. Avec la collaboration de Albert Riedlinger. Lausanne, Paris: Payot/ Course in general linguistics (American English edition from the first French edition), trans. W. Baskin. New York, NY: Philosophical Library.

Skalička, V. (1979). Typologische studien. Braunschweig: Vieweg.

Thomason, S. G. (2001). Language contact. Edinburgh: Edinburgh University Press.

Wąsik, Z. (2003). Epistemological perspectives on linguistic semiotics. Frankfurt am Main: Peter Lang. Europäischer Verlag der Wissenschaften. 
Wheeler, M. W. (1993). On the hierarchy of naturalness principles in inflectional morphology. Journal of Linguistics, 29(1), 95-111.

\author{
Elżbieta Magdalena Wąsik \\ Poznanès Adomo Mickevičiaus universitetas, Lenkija \\ wasik@wa.amu.edu.pl
}

\title{
KALBOS KINTAMUMO IR VARIANTIŠKUMO NATŪRALUMAS KONTAKTO SITUACIJOSE: KALBOS SAVYBĖ AR KOMUNIKUOJANČIO INDIVIDO LINGVISTINĖS VEIKOS REZULTATAS
}

\begin{abstract}
Santrauka. Straipsnyje analizuojama kalbu tarpusavio itaka taikant du analitinius požiūrius: pirmuoju požiūriu analizuojama pati kalba, antruoju - dèmesys sutelkiamas i komunikuojančiu individu analizę. Nagrinèjama iki kokio lygio tiesioginio kontakto paveiktos kalbos plètojimas priklauso nuo tam tikros kalbos struktūros ypatybiu, ar visgi didesnę itaką daro pašnekovu asmeninès savybès. Remiantis literatūra, susijusia su iškeltais klausimais, atskleidžiamas individo priežastinis vaidmuo kalbiniame kontekste. Tuo pačiu metu, straipsnyje teigiama, kad neskolintinu kalbos elementu ir struktūru paieška reikalauja apibrèžti natūralumo, žymètumo bei nežymètumo savokas per žmogiškuju gebejjimu prizmę. Žvelgiant kritiškiau, šis straipsnis pagrindžia teigini, kad principus, kurie lemia tiesioginio kontakto paveiktus kalbos pokyčius individo komunikaciniu gebejjimu požiūriu, galima atskleisti išnagrinèjus daugiakalbiu individu asmeninio bei grupès identiteto formavimassi, labiausiai pasireiškianti kodu kaitos kontekste, iš dalies kalbos perkèlimo bei leksiniu ir gramatiniu prielaidu raiškos kontekste. Taigi straipsnio autorès manymu lingvistinio kintamumo ir variantiškumo ištakos kontakto situacijose pirmiausiai turètu būti suvokiamos per socialiai ir kultūriškai apibrež̌tu kalbos vartotoju asmeninę itaką. Apibendrinant, šiuo darbu stengiamasi irodyti, kad lingvistiniai skoliniai negali būti analizuojami remiantis universaliais pritaikomumo principais ar absoliutumu. Ši analizè turètu remtis žmogiško suvokimo principais, gebejimu isiminti ir apibendrinti, taip pat ir komunikavimo pastangy ekonomijos principais, susijusiais su individualiais bei sociokultūriniais poreikiais, žiniomis ir požiūriais.
\end{abstract}

Pagrindinès sąvokos: idiolektas, kalbos kaita, kalbu skirtumai, komunikuojantis individas, natūralumas, žymètumas. 